\title{
Etnomathematics: Batik Activities in Tancep Batik
}

\author{
Heru Wahyudi ${ }^{1}$, Sri Adi Widodo ${ }^{2}$, Dafid Slamet Setiana ${ }^{3}$, Muhammad Irfan ${ }^{4 *}$ \\ 1,2,3,4 Universitas Sarjanawiyata Tamansiswa \\ *muhammad.irfan@ustjogja.ac.id
}

Received: May 2021. Accepted: June 2021. Published: July 2021.

\begin{abstract}
This study aims to examine the ethnomathematics of batik activity in the Batik Tancep Gunungkidul artwork as contextual mathematics learning. This research is a type of qualitative research with an ethnographic approach. The data was obtained in the form of qualitative data, research data sources obtained through observation, interviews, documentation. The instrument in this study was the researcher himself. Data collection is done by participant observation, in-depth interviews, and documentation. The validity of the data is done by triangulation of data collection techniques and then analyzed descriptively qualitatively. Data analysis is reduced based on Bishop's mathematical fundamental activities. The results of data analysis are then explored in mathematical aspects. The results of the study found mathematical aspects of the area of flat wake area, congruence and congruence of flat wake, comparison, translation, multiplication of count numbers, and volume of curved side space. The results of the study show that the batik activity in the Batik Tancep Gunungkidul artwork is one of the real events that can be raised into contextual mathematics learning.
\end{abstract}

Keywords: ethnomatematics, tancep batik, contextual mathematics learning

How to Cite: Wahyudi, H., Widodo, S. A., Setiana, D. S., \& Irfan, M. (2021). Etnomathematics: Batik Activities in Tancep Batik. Journal of Medives: Journal of Mathematics Education IKIP Veteran Semarang, 5(2), 305-315. 


\section{PENDAHULUAN}

Matematika secara langsung dan tidak langsung digunakan oleh manusia dalam kehidupannya betapapun primitifnya suatu masyarakat, matematika telah menjadi bagian dari kebudayaannya. Bishop (1994) menyatakan matematika merupakan suatu bentuk budaya dan sesungguhnya telah terintegrasi pada seluruh aspek kehidupan masyarakat dimanapun berada. Sehingga matematika sarat dengan masalah dalam kehidupan sehari-hari. D'Ambrosio (2004) mengatakan bahwa pengajaran matematika bagi setiap orang seharusnya disesuaikan dengan budayanya. Sejalan dengan Rosa dan Orey (2011) menyatakan bahwa belajar matematika dengan baik ketika seorang guru mengajarnya terjadi interaksi sosial dan budaya melalui dialog, bahasa, melalui representasi makna simbolik dalam matematika. Selain itu, mempelajari matematika tidak hanya membekali siswa dengan matematika konseptual guna mempersiapkan siswa dalam menghadapi ujian sekolah maupun ujian nasional, namun juga mempersiapkan siswa supaya dapat menggunakan matematika dan pola pikir matematika dalam kehidupan sehari-hari dan dalam mempelajari berbagai pengetahuan (Sudirman, dkk, 2017). Sehingga mempelajari matematika sangat penting di dalam kehidupan manusia. Hal ini karena matematika merupakan pengetahuan yang universal (Muhtadi, 2017).

Pembelajaran matematika sekolah terkadang berbeda dengan permasalahan matematika yang ditemukan dalam kehidupan sehari-hari (Andriyani, 2017). Sejalan dengan Rosa dan Orey (2011) bahwa ada perbedaan antara pengetahuan matematika yang diperoleh secara akademis dan informal. Kurangnya unsur kehidupan nyata sehari-hari di dalam pembelajaran matematika dapat menimbulkan kesulitan siswa dalam menerapkan matematika untuk menyelesaikan masalah dalam kehidupan seharihari. Adanya kesulitan siswa dalam menghubungkannya dengan kehidupan nyata menyebabkan pentingnya pengintegrasian pembelajaran berbasis budaya dalam pembelajaran (Andriyani, 2017). Sehubungan dengan hal tersebut Suwarsono (2015) menyatakan adanya wajah seram terhadap matematika sebagai pelajaran yang membosankan, kurang menarik, dan jauh dari kehidupan sehari-hari. Sejalan dengan Dominikus, dkk (2017) fakta menunjukkan bahwa pembelajaran matematika di sekolah sering tidak menggunakan budaya sebagai konteks pembelajaran. Salah satu pendekatan pembelajaran yang dapat digunakan oleh guru mengatasi kondisi tersebut yaitu pembelajaran kontekstual.

Pembelajaran kontekstual adalah konsep yang membantu guru mengaitkan antara materi yang diajarkannya dengan situasi dunia nyata dan mendorong siswa membuat hubungan antara pengetahuan yang dimilikinya dengan penerapan dalam sehari-hari (Afriani, 2018). Salah satu kehidupan sehari-hari yang bersinggungan langsung dengan siswa yaitu budaya. Marsigit, dkk (2017) juga mengatakan bahwa salah satu aspek yang dapat dikembangkan untuk inovasi pembelajaran adalah budaya lokal setempat. Suatu cara untuk menjembatani budaya 
dan matematika yaitu etnomatematika. Etnomatematika dapat menjembatani antara budaya yang ada di masyarakat dan pendidikan (Wahyuni, dkk, 2013). Selain itu Hartoyo (2012) mengatakan istilah etnomatematika digunakan untuk menunjuk matematika yang terdapat dalam lingkungan masyarakat, berkaitan dengan latar belakang sosial, ekonomi, dan budaya suatu masyarakat. Etnomatematika juga dapat dipersepsikan sebagai lensa untuk memandang dan memahami matematika sebagai produk budaya (Puspadewi \& Gst. Ngurah Nila Putra, 2014). Dalam konteks pembelajaran matematika etnomatematika adalah pembelajaran yang menggunakan simbol-simbol budaya untuk memunculkan konsep-konsep matematika (Wijayanto, 2017). Dengan demikian matematika sarat dengan masalah dalam kehidupan sehari-hari. Hal ini sejalan dengan pandangan Freudental dan Gravemeijer, bahwa matematika sebagai aktivitas manusia (Athar, 2012).

Aktivitas matematika adalah aktivitas yang di dalamnya terjadi proses pengabstraksian dari pengalaman nyata dalam kehidupan sehari-hari ke dalam matematika atau sebaliknya, yang meliputi aktivitas mengelompokkan, berhitung, mengukur, merancang bangunan atau alat, membuat pola, membilang, menentukan lokasi, bermain, menjelaskan, dan sebagainya (Rachmawati, 2012). Sejalan dengan Bishop (1988) mengelompokkan aspek matematika berdasarkan enam aktivitas matematika fundamental, yaitu counting (membilang), locating (menentukan lokasi), measuring (mengukur), designing (mendesain), playing (bermain), dan explaining (menjelaskan). Sedangkan bentuk etnomatematika yaitu berupa hasil dari aktivitas matematika yang ada dan berkembang dalam kebudayaan masyarakat tertentu.

Salah satu karya budaya adiluhung yang sarat dengan makna simbolik adalah batik (Sedjati, 2019). Batik merupakan warisan budaya yang telah ditetapkan oleh UNESCO sebagai Masterpieces of the Oral and Intangibel Heritage of Humanity. Pada tanggal 2 Oktober, secara resmi ditetapkan sebagai hari batik nasional sebagai wujud kebanggan bangsa Indonesia terhadap batik yang telah mendapatkan pengakuan dunia dan menjadi warisan budaya yang patut dikembangkan (Arwanto, 2017). Sejak saat itu batik mulai banyak dikembangan di berbagai daerah di Indonesia. Hingga saat ini batik berada di puncak popularitas (Iskandar dan Kustiyah, 2017). Begitu pula dengan Batik Tancep yang ada di Gunungkidul.

Batik Tancep merupakan salah satu motif batik tertua warisan budaya asli dari Gunungkidul (Hermawan, dkk, 2013). Pembuatan Batik Tancep masih menggunakan cara tradisional dengan pembuatan motif secara manual dan pewarnaannya menggunakan bahan alami. Ciri khas utama Batik Tancep yaitu banyak batik yang diproduksi dengan warna biru keungu-unguan, hijau, dan coklat. Batik Tancep Gunungkidul memiliki motif dan warna yang sedikit berbeda dengan jenis batik khas Yogyakarta dan batik khas Solo. Kedua jenis batik tersebut menjadi perbandingan Batik Tancep, karena letak Gunungkidul yang berada di tengah-tengah 
antara Yogyakarta dan Solo. Proses membatik Batik Tancep ini seperti proses membatik pada umumnya. Proses membatik tulis yang dilakukan secara berturu-turut yaitu: (1) nyorek adalah membuat pola diatas kain dengan cara meniru pola yang sudah ada, (2) noled adalah memberi warna pada kain batik dengan zat warna yang dikanvaskan atau dilukiskan dimana daerah yang diwarnai itu dibatasi oleh garis-garis lilin sehingga warna tidak meluas ke daerah yang lainnya, (3) nembok adalah mengeblok bagian pola yang tidak kan diwarnai atau akan diwarnai dengan warna yang lain, (4) medel adalah pencelupan kain yang sudah dibatik ke cairan warna secara berulang kali hingga mendapatkan warna yang dikehendaki, 5) lorod adalah melepaskan malam dengan memasukkan kain ke dalam air mendidih yang sudah dicampuri bahan untuk mempermudah lepasnya lilin. Sedangkan batik cap, proses yang dilakukan secara berturutturut yaitu mencap, noled, nembok, medel, dan lorod.

Berdasarkan pemaparan tersebut, penelitian ini bertujuan untuk mengkaji etnomatematika aktivitas membatik pada karya seni Batik Tancep Gunungkidul.

\section{METODE PENELITIAN}

Penelitian ini menggunakan jenis penelitian kualitatif dengan pendekatan etnografi. Sesuai dengan jenis penelitian kualitatif dengan pendekatan etnografi, instrumen penelitian ini adalah peneliti sendiri (human instrument). Peneliti berperan sebagai human instrument yang tidak digantikan perannya, sehingga peneliti sebagai instrumen utama. Dalam pelaksanannya peneliti dibantu instru- men lainnya berupa catatan lapangan, dokumentasi dan pedoman wawancara. Pedoman wawancara berisi kisi-kisi wawancara yang akan dijadikan acuan dalam menggali informasi dari narasumber dalam menemukan informasi mengenai proses membatik.

Teknik pengumpuan data yang digunakan dalam penelitian ini yaitu observasi, wawancara, dan dokumentasi. Setelah data dikumpulkan kemudian direduksi hingga memperoleh keabsahan dengan uji kredibilitas data penelitian yang menggunakan triangulasi teknik pengumpulan data. Triangulasi teknik digunakan untuk menguji kredibilitas data dilakukan dengan cara mengecek data kepada sumber yang sama dengan teknik yang berbeda melalui wawancara, observasi dan dokumentasi (Sugiyono, 2017).

Analisis data penelitian ini dilakukan sejak sebelum memasuki lapangan, selama di lapangan, dan setelah di lapangan. Peneliti menggunakan teknik analisis data Model Interaktif Miles dan Huberman yang analisis datanya dilakukan secara interaktif dan berlangsung secara terus menerus sampai tuntas sehingga datanya jenuh. Hasil analisis data direduksi berdasarkan aktivitas fundamental matematika menurut Bishop. Penarikan kesimpulan dilakukan dari data yang tersaji kemudian diverifikasi dengan meninjau kembali studi pustaka, observasi, wawancara, dan hasil dokumentasi. Kesimpulan tersebut senantiasa diverifikasi selama penelitian berlangsung untuk memperoleh kesimpulan yang akurat. 


\section{HASIL DAN PEMBAHASAN}

Aktivitas membatik direduksi berdasarkan aspek fundamental matematis menurut Bishop, yaitu: (1) aktivitas counting terdapat pada proses membuat campuran warna dan pengunci warna noled, waktu yang digunakan noled, kebutuhan air dan campuran dalam proses lorod, kebutuhan malam dalam proses nyanting-nembok, pembuatan campuran warna dan pengunci warna pada proses medel; (2) aktivitas locating yang terdapat pada kegiatan membatik yaitu lay out batik cap, posisi duduk dalam proses nembok, penempatan planggrangan pada proses mbedel; (3) aktivitas measuring yang terdapat pada kegiatan membatik yaitu pengukuran kain batik cap; (4) aktivitas designing yang terdapat pada kegiatan membatik yaitu membuat pola batik tulis dan menentukan motif batik cap; (5) aktivitas playing yang terdapat pada kegiatan membatik yaitu teknik mencap batik dan proses proses medel (pewarnaan) kain batik; (6) aktivitas explaining yang terdapat pada aktivitas membatik yaitu teknik mencap batik dan proses melorod kain batik.

Berdasarkan hasil pemaparan di atas, aktivitas membatik karya seni Batik Tancep memiliki aspek-aspek etnomatematika. Aspek-aspek tersebut adalah sebagai berikut.

\section{Luas Daerah Bangun Datar}

Dalam mencap batik, luas daerah pencapan ditentukan menggunakan ukuran cap dengan masing-masing sisi diberi spasi, cap yang digunakan ukuran $14 \times 14 \mathrm{~cm}$ tepi panjangnya diberi spasi $2 \mathrm{~cm}$ dan lebarnya $1 \mathrm{~cm}$, cap ukuran
$18 \times 18 \mathrm{~cm}$ panjangnya $1 \mathrm{~cm}$ dan lebarnya $5 \mathrm{~cm}$. Aktivitas yang dilakukan tersebut ditemukan aspek matematika berupa konsep luas daerah bangun datar.

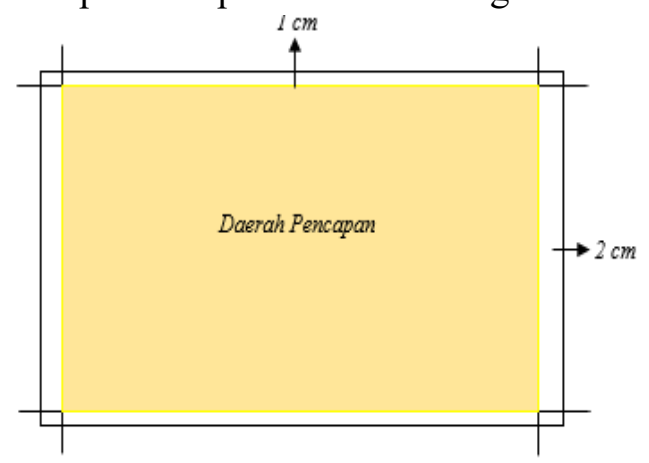

Gambar 1. Daerah Pencapan Ukuran $14 \times 14 \mathrm{~cm}$

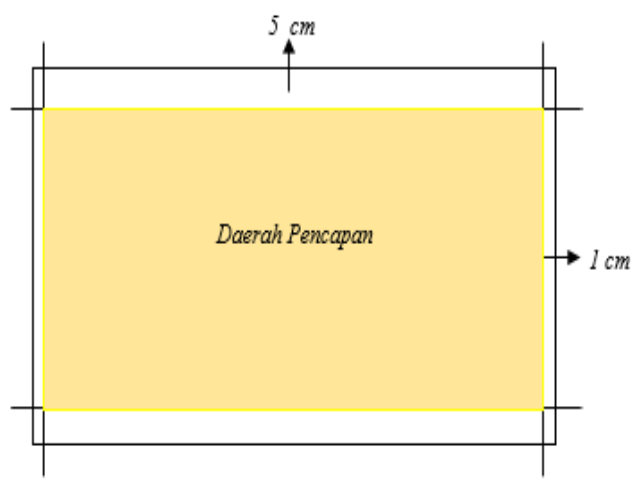

Gambar 2. Daerah Pencapan Ukuran $18 \times 18 \mathrm{~cm}$

Daerah pencapan dapat dipandang sebagai bentuk persegi panjang, sehingga daerah pencapan merupakan luas persegi panjang. Secara matematis luas daerah pencapan dapat dirumuskan sebagai

$$
\boldsymbol{L}=\boldsymbol{p} \times \boldsymbol{l}
$$

Keterangan:

$L$ : Luas daerah pencapan

$p$ : Panjang daerah pencapan

$l$ : Lebar daerah pencapan

\section{Kongruensi dan Kesebangunan Bangun Datar}

Mencap batik dilakukan dengan cara menyanggit sesuai ukuran capnya. 
Teknik tersebut dimulai dari ujung bawah kiri kain kemudian ke atas dan dilanjut menggeser ke sebelah kanan dengan ukuran penuh yang dimulai dari serong kanan atas pencapan pertama (ujung bawah kiri kain). Aktivitas yang dilakukan tersebut ditemukan aspek matematika berupa konsep kongruensi dan kesebangunan bangun datar. Hasil pencapan yang membentuk kotak-kotak dapat dipandang sebagai konsep kekongruenan dan kesebangunan bangun datar.

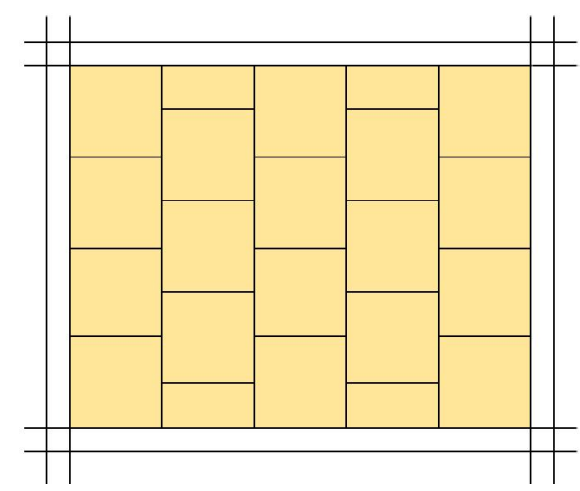

Gambar 3. Hasil Pencapan

Kongruensi adalah konsep dua bangun geometri atau lebih yang saling sama dan sebangun. Dua bangun geometri atau lebih disebut saling kongruen atau sama apabila unsur-unsur yang bersesuaian pada bangun-bangun tersebut saling sama dan sebangun. Ciriciri kongruensi yaitu: (a) sisi-sisi yang bersesuaian sama panjang, (b) sudutsudut yang bersesuaian sama besar.

Kesebangunan adalah konsep dua bangun atau lebih yang bersesuaian saling proporsional (sebanding). Ciri-ciri kesebangunan yaitu: (a) sudut-sudut yang bersesuaian (seletak) pada kedua bangun datar sama besar, (b) perbandingan panjang sisi-sisi yang bersesuaian (seletak) pada kedua bangun datar sama.

\section{Perbandingan Senilai}

Pada proses nembok terdapat kegiatan memperkirakan kebutuhan pengunaan malam. Asumsi kebutuhan malam dalam proses menembok satu kain batik yaitu 1 ons sampai 1,5 ons yang dipengaruhi oleh motif batik pada kain. Pada motif Walang Kencana Jati, satu kain membutuhkan 1,5 ons malam untuk ukuran kain $2 \times 1$ meter. Ketika akan menembok sembilan kain, asumsi kebutuhan malamnya 13,5 ons. Aktivitas yang dilakukan tersebut ditemukan aspek matematika berupa konsep perbandingan senilai. Perbandingan senilai merupakan upaya membandingkan dua obyek atau lebih dengan besar salah satu nilai variabel yang bertambah maka membuat variabel lain menjadi bertambah juga. Hal tersebut dapat dirumuskan sebagai berikut.

$$
\frac{a_{1}}{b_{1}}=\frac{a_{2}}{b_{2}}
$$

\section{Perbandingan Berbalik Nilai}

Aktivitas nembok dan noled terdapat kegiatan memperkirakan waktu pengerjaannya. Pada proses nembok, terdapat keterampilan menembok yang dikategorikan rendah, sedang, dan tinggi. Untuk menyelesaikan nembok satu kain kategori rendah membutuhkan waktu 2 jam, kategori sedang 1,5 jam dan kategori tinggi 1 jam. Sedangkan pada proses noled, waktu yang dibutuhkan noled satu kain yaitu 30 menit dan 15 menit jika dikerjakan oleh dua orang pembatik. Aktivitas yang dilakukan tersebut ditemukan aspek matematika berupa konsep perbandingan berbalik nilai. Perbandingan berbalik nilai yaitu upaya membandingkan dua 
objek atau lebih dengan besar nilai salah satu variabel yang bertambah maka membuat variabel lain menjadi berkurang nilainya. Hal tersebut dapat dirumuskan sebagai berikut.

$$
\frac{a_{1}}{b_{2}}=\frac{a_{2}}{b_{1}}
$$

\section{Translasi}

Aktivitas mencap batik dilakukan dengan cara menggeser cap sesuai ukuran kainnya. Dalam mencap batik, mencap batik dilakukan dengan cara menyanggit sesuai ukuran capnya. Teknik tersebut dimulai dari ujung bawah kiri kain kemudian ke atas dan dilanjut menggeser ke sebelah kanan dengan ukuran penuh yang dimulai dari serong kanan atas pencapan pertama (ujung bawah kiri kain). Aktivitas yang dilakukan tersebut ditemukan aspek matematika berupa konsep translasi (geseran). Translasi adalah suatu perpindahan semua titik pada suatu bidang dengan jarak (besar) dan arah yang sama.

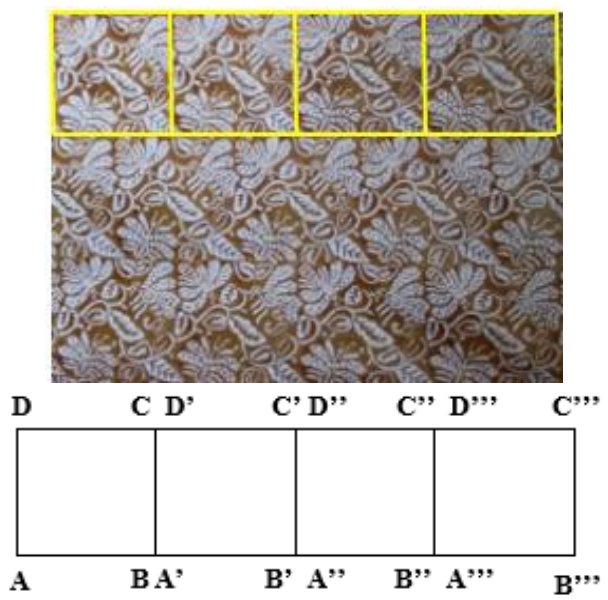

Gambar 4. Motif Batik dan Translasi pada Motif

Jika gambar motif Walang Kencana Jati pada Batik Tancep digeser horizontal ke kanan sejauh $k_{1}$ satuan, kemudian digeser lagi $k_{2}$ dan $k_{3}$ satuan ke arah yang sama, maka kita dapat menemukan konsep dasar translasi. Pada motif tersebut, bangun persegi $A B C D$ ditranslasikan tiga kali sejauh $k$ satuan ke kanan sejajar sumbu $X$ dan menghasilkan bangun $A^{\prime} B^{\prime} C^{\prime} D^{\prime}$, bangun $A^{\prime \prime} B^{\prime \prime} C^{\prime \prime} D^{\prime \prime}$, dan bangun $A^{\prime \prime \prime} B^{\prime \prime \prime} C^{\prime \prime \prime} D^{\prime \prime \prime}$. Secara matematika, rumus translasi dapat dituliskan sebagai berikut.

$$
A(x, y)\left(\begin{array}{l}
a \\
b
\end{array}\right) \rightarrow A^{\prime}(x+a, y+b)
$$

\section{Perkalian}

Kegiatan mencap batik merupakan rangkaian proses dalam membatik. Pada kegiatan tersebut terdapat aktivitas pengukuran kain batik dan perkiraan penggunaan malam. Untuk menghitung penggunaan malam menggunakan satuan balok. Satu balok malam dapat digunakan untuk mencap kain batik ukuran 2,5 × 1,5 meter sebanyak 7 kain, 2 balok untuk 14 kain, 3 balok untuk 21 kain dan seterusnya berlaku kelipatan 7 . Pada pengukuran kain batik cap sering menggunakan alat ukur sederhana yaitu dilakukan menggunakan cap batik ukuran $20 \times 20 \mathrm{~cm}$. Untuk mendapatkan ukuran kain yang diinginkan, pembatik melakukan pengukuran terhadap kain batik dengan menggeser berkali-kali cap tersebut sesuai kebutuhan. Apabila membutuhkan kain ukuran $2 \times 1$ meter, maka pembatik menggeser cap sepuluh kali dan untuk mendapatkan ukuran $2,5 \times 1,5$ meter pembatik menggeserkan cap sebanyak 25 kali kemudian dibagi menjadi dua bagian, sedangkan untuk lebar sudah sesuai ukuranya sejak pembelian. Aktivitas yang dilakukan tersebut 
ditemukan aspek matematika berupa perkalian. Perkalian adalah penjumlahan berulang, atau penjumlahan dari beberapa bilangan yang sama. Perkalian didefinisikan sebagai penjumlahan berganda dengan suku-suku yang sama. Misal bilangan-bilanganya $a$ dan $b$, maka $a \times b$ adalah penjumlahan yang mempunyai $a$ suku, dan tiap-tiap suku sama dengan $b$, dengan rumus

$$
\begin{aligned}
a \times b= & b+b+\cdots+b \\
& (\text { sebanyak a suku) }
\end{aligned}
$$

Jika $a \times b$ dinamakan $c$, maka terdapat $a \times b=c$ yang dibaca " $a$ kali $b$ sama dengan $c$ " dimana $a$ adalah pengali, $b$ adalah bilangan yang dikalikan, dan $c$ adalah hasil kali.

\section{Volume Bangun Ruang Sisi Lengkung}

Kegiatan lorod merupakan rangkaian proses dalam membatik. Pada proses tersebut terdapat aktivitas memperkirakan kebutuhan penggunaan cairan lorod yang dituangkan dalam kenceng dan aktivitas memperikirakan pengisian dua bak pembilasan. Aktivitas yang dilakukan tersebut ditemukan aspek matematika berupa konsep volume.

\section{Aktivitas Memperkirakan Kebutuhan Penggunaan Cairan Lorod}

Cairan lorod yang digunakan tidak sampai memenuhi kenceng, tetapi diberi sedikit ruang kosong untuk menghindari tumpahnya cairan.
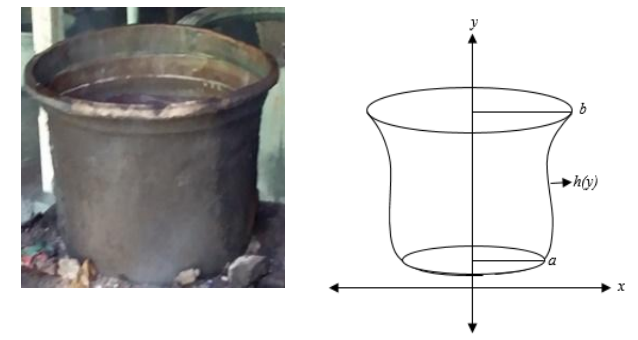

Gambar 5. Kenceng

Volume kenceng dapat dipandang sebagai banyaknya campuran yang ditampung di dalam kenceng. Volume kenceng merupakan suatu fungsi $h$ yang diputar terhadap sumbu $y$ dan dibatasi oleh $y_{1}=a$ dan $y_{2}=b . \quad$ Secara matematis volume kenceng dapat dirumuskan sebagai berikut.

$$
V=\pi \int_{a}^{b}(h(y))^{2} d y
$$

Keterangan:

$V$ : volume kenceng

$b$ : batas atas kenceng

$a$ : batas bawah kenceng

$h$ : sisi kenceng

$y$ : sumbu putar kenceng

\section{Penggunaan Air Bersih Untuk Mengisi Bak Pembilasan}

Air bersih yang digunakan tidak sampai memenuhi bak, tetapi diberi sedikit ruang kosong untuk menghindari tumpahnya air.

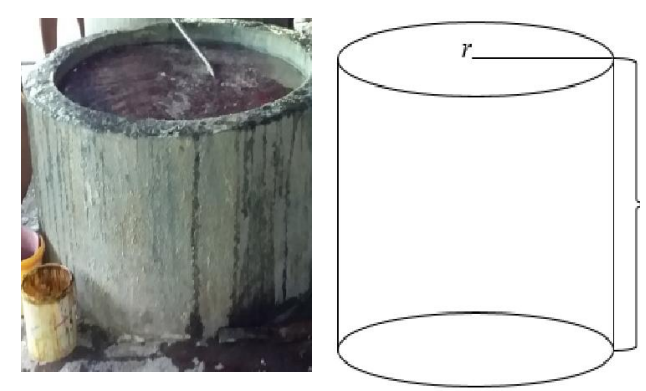

Gambar 6. Bak Air 
Bak dapat dipandang sebagai bentuk tabung sehingga volume bak merupakan volume suatu tabung. Secara matematis volume bak dapat dirumuskan sebagai berikut.

Keterangan:

$V$ : volume bak

$\pi$ : phi $\left(\frac{22}{7}\right.$ atau 3,14$)$

$r$ : jari-jari bak

$t$ : tinggi bak

Berdasarkan uraian di atas, diperoleh bahwa aktivitas membatik pada karya seni Batik Tancep Gunungkidul memiliki aspek-aspek matematika yang terkandung di dalamnya. Aspek-aspek tersebut dapat digunakan sebagai pembelajaran matematika kontekstual seperti berikut.

Kegiatan lorod merupakan rangkaian proses dalam membatik. Pada proses tersebut terdapat aktivitas memperikirakan pengisian dua bak pembilasan. Aktivitas yang dilakukan tersebut ditemukan aspek matematika berupa konsep volume. Air bersih yang digunakan tidak sampai memenuhi bak, tetapi diberi sedikit ruang kosong untuk menghindari tumpahnya air. Bak dapat dipandang sebagai bentuk tabung sehingga volume bak merupakan volume suatu tabung. Dari aktivitas tersebut dapat dijadikan contoh soal permasalahan kontekstual.

\section{PENUTUP}

Aktivitas membatik pada karya seni Batik Tancep Gunungkidul diawali dengan membuat motif batik pada kain, kemudian motif yang sudah terpola diberi cairan malam menggunakan canting atau cap batik. Setelah semua motif telah diberi cairan malam bagian motif yang dikehendaki warna tertentu diwarnai, bagian-bagian tersebut kemudian diblok menggunakan cairan malam. Selanjutnya kain dicelupkan pada cairan pewarna dasar kain. Proses terakhir menghilangkan malam yang ada pada kain hingga bersih kemudian ditiriskan dan dijemur hingga kering. Aktivitas membatik tersebut merupakan salah satu peristiwa nyata yang dapat digunakan sebagai pembelajaran matematika kontekstual. Keterkaitan dengan aktivitas matematika dapat dilihat dari penjabaran aktivitas membatik melalui aspek matematis berdasarkan aktivitas fundamental matematika menurut Bishop. Aspekaspek matematika yang teridentifikasi dari aktivitas membatik yaitu luas daerah bidang datar, kongruensi dan kesebangunan bangun datar, perbandingan, translasi, perkalian bilangan cacah dan volume bangun ruang sisi lengkung. Hal ini menunjukan bahwa matematika terdapat pada aktivitas kehidupan manusia seperti halnya budaya yang dalam hal ini adalah aktivitas membatik karya seni Batik Tancep Gunungkidul. Pembelajaran matematika dapat menerapkan budaya membatik sebagai pembelajaran matematika kontekstual sehingga lebih inovatif dan tidak membosankan. Diharapkan pembelajaran matematika menjadi lebih bermakna dan menyenangkan sehingga siswa lebih mudah dalam memahami konsep matematika melalui aktivitas membatik karya seni Batik Tancep. 


\section{DAFTAR PUSTAKA}

Afriani, A. (2018). Pembelajaran Kontekstual (Cotextual Teaching and Learning) dan Pemahaman Konsep Siswa. Jurnal AlMuta aliyah : Jurnal Pendidikan Guru Madrasah

Ibtidaiyah. 1(3), 80- 88.

Andriyani, \& Kuntarto. (2017). Etnomatematika: Model Baru dalam Pembelajaran. Jurnal Gantang. Vol. 2 No. 2. 133-144.

Arwanto, A. (2017). Eksplorasi Etnomatematika Batik Trusmi Cirebon untuk Mengungkap Nilai Filosofi dan Konsep Matematis. Phenomenon: Jurnal Pendidikan MIPA. (Vol.7 Nomor 1). Hlm. 4049.

Bishop, A. J. (1988). Mathematical Enculturation: a cultural perpective on Mathematics

Education. Kluwer Academic Publisher. Dordrecht. Boston. London.

Bishop, A. J. (1994). Cultural Conflicts in Mathematics Education: Developing a Research Agenda. For the Learning Mathematics 14(2): $15-18$.

D’Ambrosio, U. (2004). Peace, social justice and ethnomathematics The MontanaMathematics Enthusiast, Monograph 1, pp.25-34.

Dominikus, W.S., dkk. (2016). Link Between Ethnomathematics In Marriage Tradition In Adonara Island And School Mathematics. IOSR Journal of Research \& Method in Education (IOSR-JRME), 3 (6) 56-62.

G. A, Athar. (2012). Pengembangan Pembelajaran Matematika dengan Pendekatan Pendidikan Matematika Realistik (PMR)
Berbasis Budaya Cerita Rakyat Melayu Riau. Prosiding Seminar Nasional Matematika dan Pendidikan Matematika. Univerisitas Negeri Yogyakarta : Yogyakarta.

Hartoyo, Agung. (2012). Eksplorasi Etnomatematika Pada Budaya Masyarakat Dayak Perbatasan Indonesia-Malaysia Kabupaten Sanggau Kalbar. Jurnal Penelitian Pendidikan. 13 (1), 14-23.

Hermawan, dkk. (2013). Pengembangan Usaha Batik Tancep di Dusun Sumberan, Desa Tancep, Kecamatan Ngawen, Ngawen, Kabupaten Gunungkidul. Jurnal Penelitian dan Pengembangan Pemerintah Daerah DIY. 5(7) 1520.

Iskandar dan Eny Kustiyah. (2017). Batik Sebagai Identitas Kultural Bangsa Indonesia Di Era Globalisasi. GEMA,THN XXX/52/Agustus 2016 -Januari 2017. Hlm. 2456-2472.

Marsigit, dkk. (2017). Pengembangan Pembelajaran Matematika Berbasis Etnomatematika, Prosiding Seminar Nasional Etnomatnesia. Hlm. 20-38.

Muhtadi, D. (2017). Sundanese Etnomathematics: Mathematical Activities in Estimating, Measuring, and Making Patterns. Journal on Mathematics Education, 8(2), 185-198.

Puspadewi, K. R., \& Gst. Ngurah Nila Putra, I. (2014). Etnomatematika di Balik Kerajinan Anyaman Bali, Jurnal Matematika. 4(2).80-89.

Rachmawati, Inda. (2012) Eksplorasi Etnomatematika Masyarakat Sidoarjo. MATHEdunesa: Jurnal Pendidikan Matematika. 1(1). 
Rosa, M., \& Orey, D. C. (2011). Ethnomathematics: The Cultural Aspects of Mathematics. Revista Latinoamericana de Etnomatematica, 4(2), 32-54.

Sedjati, Djandjang Purwo. (2019). Keben (Barringtonia Asiatica), Motif dan Pewarna Batik. Jurnal Seni Kriya. 2(2) 98-107.

Sudirman, dkk. (2017). Penggunaan Etnomatematika Pada Karya Seni Batik Indramayu Dalam Pembelajaran Geometri Transformasi. Pedagogy 2(1) 7485.

Sugiyono. (2017). Metode Penelitian Kuantitatif, Kualitatif, dan $R \& D$. Bandung: Alfabeta.

Suwarsono. (2015). PPT Etnomatematika (Ethnomatematics) Materi Kuliah S2 Pendidikan Matematika Universitas Sanata Dharma.

Wahyuni, Astri, dkk. (2013). Peran Etnomaematika Dalam Membangun Karakter Bangsa, Jurnal Pendidikan Matematika FMIPA. Pascasarjana Universitas Negeri Yogyakarta.

Wijayanto, Z. (2017). Pengembangan Perangkat Pembelajaran Matematika Berbasis Etnomatematika Pada Keraton Yogyakarta. SOSIOHUMANIORA : Jurnal Ilmiah Ilmu Sosial Dan Humaniora, 3(1). 